\title{
Prevention and Treatment of Obesity and Diabetes and their Related Complications
}

\author{
Moon K Song ${ }^{1,2 *}$, David S Bischoff ${ }^{1,2}$, Koichi Uyemura ${ }^{1,2}$, Albert M Song $^{1,3}$ and Dean T Yamaguchi ${ }^{1,2}$ \\ ${ }^{1}$ Research Service, VA Greater Los Angeles Healthcare System, North Hills CA 90073, USA \\ ${ }^{2}$ Department of Pediatrics and Medicine, UCLA School of Medicine, Los Angeles, CA 90095, USA \\ ${ }^{3}$ Department of Surgery, Kaiser Permanente Medical Center Panorama City CA 91402, USA
}

\begin{abstract}
This review article evaluates the current knowledge in the prevention and treatment of diabetes and obesity. The relative abundance of food and lack of rigorous exercise common in modern life pose serious challenges in the incidence and treatment of these diseases and their complications. Although blood glucose controlling agents such as insulin and oral hypoglycemic agents are available, most currently available drugs have been shown to exhibit minimal to moderate efficacy and many of them have serious side effects. For example, rosiglitazone and pioglitazone are often prescribed to improve insulin sensitivity by increasing expression of glucose transporter-4 in muscle and fat cells; however, they can frequently induce cardiovascular complication and liver damage. Similarly, available anti-obesity drugs have not been very effective in reducing obesity and also exhibit many common side effects. We are presently testing a new drug, Cyclo (his-pro) plus zinc (Cyclo-Z), which prevents and treats diabetes without any known side effects. It is also very effective in animals and humans in the control of body weight. Our studies have shown that Cyclo-Z improves insulin sensitivity as measured by oral glucose tolerance test (OGTT), decreases fasting and postprandial blood glucose, diminishes $\mathrm{HbA1C}$, and reduces body weight significantly in diabetic and obese rats and humans. Studies in Goto-Kakizaki rats, a genetic model of type 2 diabetic rats, and genetically obese diabetic ob/ob mice have confirmed the ability of Cyclo-Z to improve diabetes-related clinical abnormalities and to decrease body mass index in animals. Furthermore, we have successfully completed FDAIND approved phase 1 and phase 2 a clinical trials for the treatment of diabetes alone and are currently awaiting the conclusion of another phase $2 a$ clinical trial with obese diabetic subjects. In this paper we summarize the currently available diabetes and obesity therapies and review our studies to illustrate the effective and safe ability of Cyclo-Z to reduce and treat patients suffering from diabetes and obesity.
\end{abstract}

Keywords: Diabetes; Obesity; Cyclo (His-Pro); Zinc; Insulin resistance; Leptin resistance

\section{Introduction}

Approximately 26 million patients in the United States are afflicted with Type 2 or Non-Insulin-Dependent Diabetes Mellitus (NIDDM) (National Diabetes Fact Sheet, Jan 26, 2011). Worldwide, 370-382 million patients are estimated to be diabetic $[1,2]$. The major defect in patients with type 2 diabetes (T2D) is the functional impairment of insulin action on peripheral tissues to stimulate glucose uptake, to decrease gluconeogenesis, and to inhibit hepatic glucose output. Although these defects are caused by both genetic and environmental factors, the ultimate outcome of diabetes is largely induced by environmental factors [3]. Insulin-mediated signal transduction mechanisms are extremely complex, involving more than 100 proteins and enzymes [4,5]. Parenteral insulin or oral hypoglycemic agents (to stimulate pancreatic insulin secretion), and metformin (to inhibit hepatic glucose output) are effective only for lowering blood glucose levels. Metformin can be toxic to humans [6]. Rosiglitazone and pioglitazone are thought to improve insulin sensitivity, but these agents pose possible cardiac enlargement, liver damage or bladder cancer [7,8]. Glucagon-like protein-1 (GLP-1) has been shown to reduce Hemoglobin $(\mathrm{Hb})$ Alc levels by $0.98 \%$ during a 16 weeks trial, but was found to induce gastric discomfort [9]. It also has serious disadvantages to use for routine therapy due to parenteral treatment for low efficacy benefit [10]. Dipetidyl peptidase-4 (DPP-4) degrades GLP-1, and its inhibition increases circulating GLP-1. Thus, DPP4 inhibitor treatment resulted in decreased HbAlc by 0.39 to $0.56 \%$ $(\mathrm{p}<0.05)$ and fasting plasma glucose 11.0 to $17.2 \mathrm{mg} / \mathrm{dL}(\mathrm{p}<0.05)$ in a 12 week randomized, double blind study with $100 \mathrm{mg}$ daily dose [11]. DPP-4 inhibitor plus $2000 \mathrm{mg}$ metformin treatment decreased HbAlc levels $2.07 \%$ whereas metformin treatment alone only reduced $1.3 \%$ [12]. Although the efficacy is not great, no serious side effect with the use of DPP-4 inhibitor was reported.

More than $80 \%$ of the US population are either overweight or obese [13] with more than $80 \%$ of diabetic subjects overweight or obese $[14,15]$. Anti-obesity drugs are only minimally effective and pose moderate to severe side effects. It has been reported that a body weight gain of 11-16 pounds increases the incidence of T2D more than twice that of normal subjects while a gain of 17-24 pounds increases the risk thrice that of normal subjects [16]. Obesity and diabetes are the leading major causes of fatal health complications including hypertension, high cholesterol, stroke, heart disease, arthritis, and certain cancers [17]. Alzheimer's disease [18,19] and osteoporosis [20,21] are also diabetes- and obesity-related complications. Extensive counseling for diet and exercise improves glucose metabolism, lipid levels, and blood pressure [22]. The most effective method for preventing and treating these metabolic diseases is to educate patients to use beneficial dietary habits along with an exercise plan and to use medication to improve

${ }^{*}$ Corresponding author: Moon K Song, Department of Pediatrics and Medicine, UCLA School of Medicine, Los Angeles, CA 90095, USA, Tel: +818 366 4085; Fax: +818 368 5603; E-mail: moon.song2@va.gov/mksong@earthlink.net

Received December 05, 2013; Accepted December 26, 2013; Published January 02, 2014

Citation: Song MK, Bischoff DS, Uyemura K, Song AM, Yamaguchi DT (2014) Prevention and Treatment of Obesity and Diabetes and their Related Complications. J Mol Genet Med S1: 009. doi: 10.4172/1747-0862.S1-009

Copyright: ( 2014 Song MK, et al. This is an open-access article distributed under the terms of the Creative Commons Attribution License, which permits unrestricted use, distribution, and reproduction in any medium, provided the original author and source are credited 
insulin resistance. Here we discuss the mechanism of a medication for diabetes and obesity including its availability, benefits and side effects. We also introduce our new drug development plan for the use of Cyclo (His-Pro) plus zinc (Cyclo-Z) for the prevention and treatment of diabetes and obesity.

\section{Materials and Methods}

Literature searches were conducted using the PubMed (http:// www.nih.gov/pubmed ) and Google websites (www.google.com ) with the following terms, key words, or phrases: Prevalence of diabetes and obesity, fact sheets of diabetes and obesity, diabetes drugs, obesity drugs, diabetes and obesity treatments, diabetes and obesity complications, diabetes and obesity co-existing diseases, relationship between diabetes and obesity, relationship between diabetes, obesity, Alzheimer's disease and osteoporosis. Clinical recommendations were synthesized based on good scientific bases from the published literature.

\section{Diabetes}

It was estimated that $2.8 \%$ of the world population was diabetic in 2000 and predicted to reach $4.4 \%$ by 2030 [23]. The risk for developing diabetes for individuals born in the year 2000 is $32.8 \%$ for males and $38.5 \%$ for females in their lifetime [24]. About 800,000 people are newly diagnosed with diabetes each year, and 200,000 people die annually from diabetes-related complications [25]. Mortality from diabetes is approximately 71,300 people each year in the US and more than 3.4 million people worldwide [26]. Global diabetes-caused deaths are also likely to increase with more than $80 \%$ of diabetes mortality occurring in low and middle income countries [27]. Total national health care expenditure in the US was $\$ 865$ billion in the year 2002, of which $\$ 160$ billion was incurred for the treatment of diabetes [28]. Diabetes treatment costs increased to $\$ 176$ billion and loss of productivity due to diabetes was estimated to be $\$ 69$ billion in the US in 2012, resulting in a total cost $\$ 245$ billion. Diabetes related health expenditure was 2.3 times greater compared to the amount spent on other health related expenses of the population without diabetes (ADA report on March 6,2013 ). The global healthcare expenditure on diabetes in 2010 was estimated to be $\$ 376$ billion and expected to increase to $\$ 490$ billion in 2030 [29]. The drug market for diabetes treatment is estimated to be over $\$ 20$ billion per year in the US alone [30].

\section{Regulation of glucose homeostasis}

Blood glucose control mechanisms are outlined in Figure 1. When glucose is absorbed through the small intestine, it is supplied to all cells through the vascular system. Pancreatic beta cells are stimulated to secret insulin, and glucose is absorbed by all cells even those without insulin-mediated uptake systems. Only muscle and fat cells require insulin for glucose uptake. Insulin also inhibits hepatic glucose output. When blood glucose is low, pancreatic alpha cells secret glucagon which stimulates hepatic glucose output. Thus, the body is able to maintain normal blood glucose levels even in the starved state. Under certain conditions such as aging, muscle cells begin to require more insulin to reach the same level of normal glucose uptake. This condition is called pre-diabetes which occurs 10-15 years prior to development of full blown diabetes and is characterized by blood glucose levels that are higher than normal even though pancreatic production and secretion of insulin is at $100 \%$ capacity.

\section{Mechanisms of insulin activity}

When insulin binds to the $\alpha$-subunit of the insulin receptor (IR$\alpha$ ), the $\beta$-subunit (IR- $\beta$ ) is auto-phosphorylated to activate its kinase activity (Figure 2). This results in a signaling cascade that leads to glucose uptake. Insulin receptor substrates (IRS) associated with src homology 2 ( $\mathrm{SH} 2$ ) activate the enzyme phosphatidylinositol 3-kinase (PI-3-kinase) which then activates Akt/protein kinase B (PKB), protein kinase $\mathrm{C}(\mathrm{PKC})$ and several unknown factors to synthesize or translocate the glucose transporter-4 (GLUT-4) to the cell membrane

\section{BLOOD GLUCOSE CONTROL MECHANISMS}

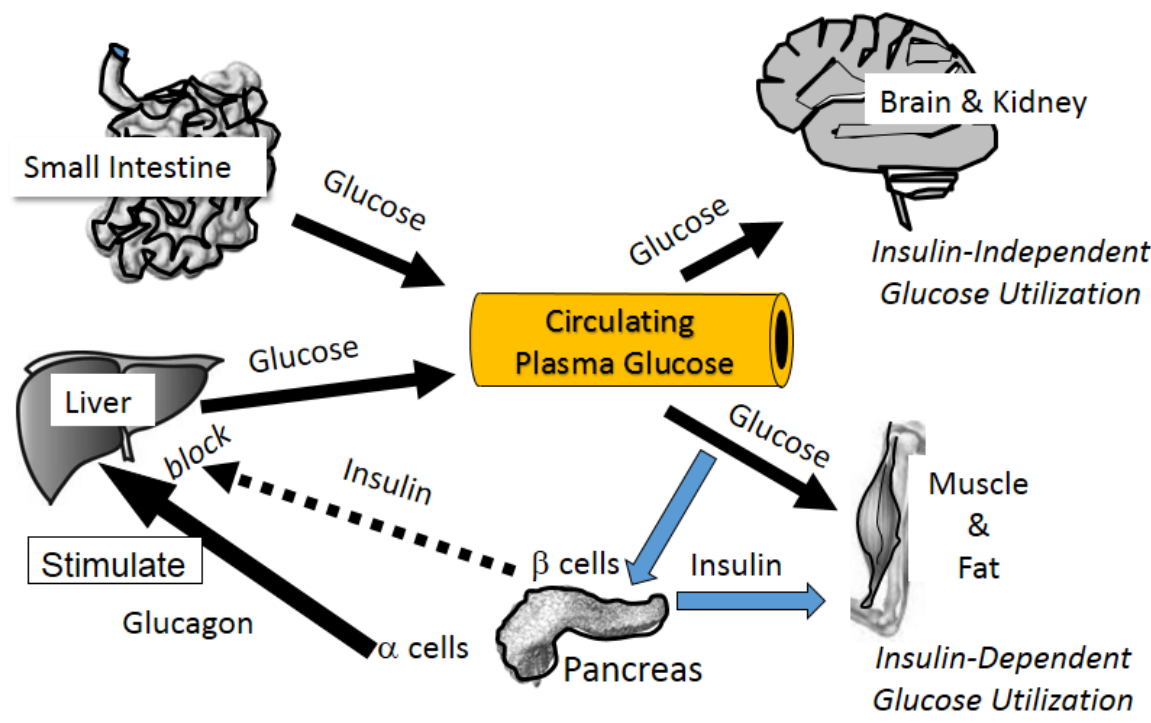

Figure 1: Blood glucose control mechanisms. When blood glucose is absorbed through the small intestine, glucose uptake activates pancreatic $\beta$-cells to synthesize and secrete insulin. Insulin signals muscle and fat cells to uptake glucose by inducing expression and translocation of the GLUT-4 transporter to the cell membrane. Insulin also blocks hepatic glucose output when blood glucose levels are higher than the normal range. When blood glucose levels are lower than the normal range, pancreatic a-cells produce glucagon and stimulate the liver to produce glucose. When insulin resistance and diabetes develop, insulin sensitivity in the insulin requiring cells are decreased, and insulin production in the pancreas will also stop in the severe diabetic condition. 
INSULIN SIGNALING

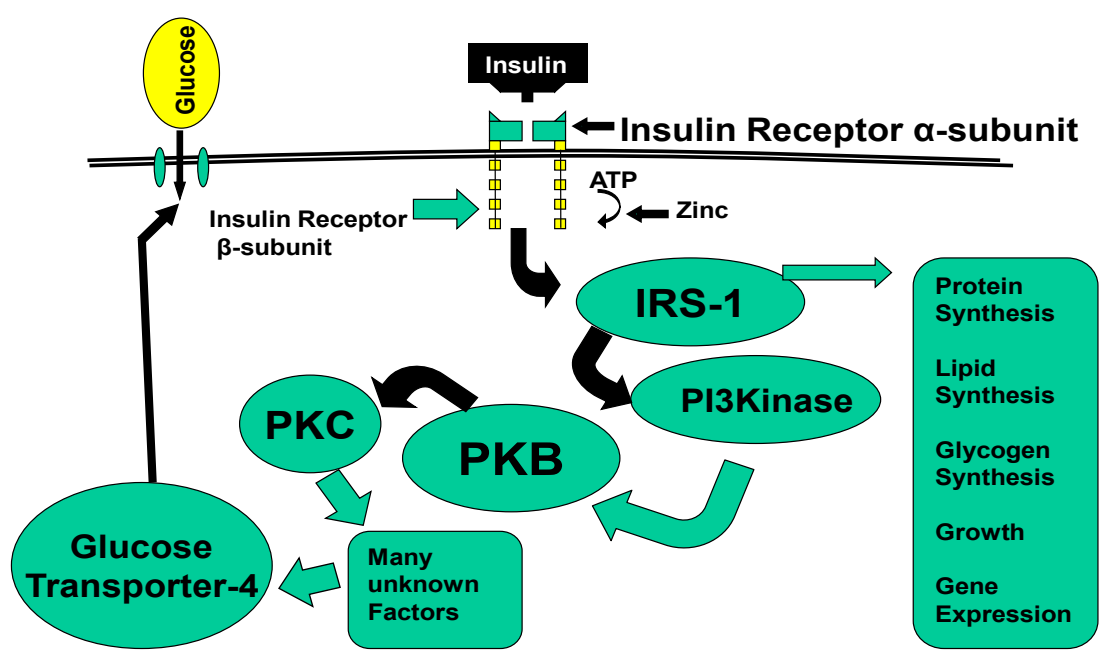

Figure 2: Insulin signal transduction mechanism for glucose uptake. When insulin binds to the $\alpha$-subunit of the insulin receptor located outside of cell membrane, it induces auto-phosphorylation of the $\beta$-subunit generating protein, lipid, and glycogen synthesis, growth, and gene expression. At the same time the signal proceed through the phosphoinositol 3' kinase, atk/protein kinase $\mathrm{B}$, and protein kinase $\mathrm{C}$ pathways eventually inducing expression and translocation of the glucose transporter-4 (GLUT-4) to the cell membrane. GLUT-4 can then transport glucose across the cell membrane. If these signaling processes are interrupted, insulin resistance and diabetes will be induced.

to allow glucose entry into the cells. One-hundred-twenty potential combinations of signaling proteins may be involved in generating the PI-3-kinase initiated signals [31].

\section{Currently recognized major anti-diabetes agents}

Insulin: There are five different categories of insulin products which are currently available.

1. Rapid acting insulin: To inject before a meal to prevent blood glucose elevation after food consumption.

2. Short acting insulin: To use 30 minutes before a meal to prevent blood glucose elevation after food consumption. This type of insulin is may also be used with longer-acting insulin Regular (R).

3. Intermediate acting insulin: This type of insulin is used with rapid- or short-acting insulin. It is normally used twice a day. NPH (N) is a prototype of intermediate acting insulin.

4. Long acting insulin: This type of insulin is also used with rapid or short acting insulin.

5. Inhalation insulin powder: Human insulin powder (Exubera ${ }^{\oplus}$ ) is inhaled instead of subcutaneous injection and it is a rapid acting insulin.

Sulfonylurea derivatives: Sulfonylurea compounds have been the backbone of oral hypoglycemic therapy in T2D treatment for more than 50 years. These drugs work by discharging more insulin from the pancreas. Sulfonylurea binds to an ATP-dependent potassium $\left(\mathrm{K}^{+}\right)$ channel on the cell membrane of pancreatic beta cells. This binding action induces the depolarization of the cell membrane resulting in the opening of voltage-gated calcium channels. The rise in intracellular calcium increases fusion of insulin granules with the cell membrane resulting in increased insulin secretion. A potential side effect is hypoglycemia. Sulfonylurea derivatives are also teratogenic and therefore cannot be used in pregnant women. However, the side effects are relatively minor compared to other anti-diabetes drugs. There are five first generation drugs and eight second generation sulfonylurea drugs. The major sulfonylurea drugs are Glyburide ${ }^{\oplus}$, Glimepiride ${ }^{\oplus}$, Glipizide ${ }^{\bullet}$, and Gliclazide ${ }^{\bullet}$.

Meglitinides: Meglitinides are a new class of drugs (phenylalanine derivative) which act similar to sulfonylurea compounds on insulin secretion. There are two commonly prescribed formulations of these drugs: Nateglinide $\left(\right.$ Starlix $\left.^{\oplus}\right)$ and repaglinide $\left(\operatorname{Prandin}^{\oplus}\right)$ which are rapidly absorbed within one hour and effective in lowering postprandial blood glucose. Therefore, it is recommended to administer the drugs 1-30 min before each meal. The normal dosage of nateglinide is 60 $120 \mathrm{mg}, 3$ times daily before each meal. Repaglinide dosage is $0.5-2 \mathrm{mg}$ before each meal with a maximum dosage of $16 \mathrm{mg} /$ day. Nateglinide is the only D-phenylalanine derivative currently approved by the FDA.

Biguanides: Metformin is a biguanide available under several brand names: Glucophage ${ }^{\oplus}$, Glucophage $\mathrm{XR}^{\oplus}$, Fortamet ${ }^{\oplus}$, Glumetza ${ }^{\oplus}$, and Riomet ${ }^{\circ}$ in 500, 850, and $1000 \mathrm{mg}$ dosage units. It is recommended to take $500 \mathrm{mg}$ twice a day or $850 \mathrm{mg}$ once daily with meals. The maximum dosage for an adult is $2550 \mathrm{mg}$ daily. Glucophage $\mathrm{XR}^{\circledR}$, Fortamet $^{\circ}$, and Glumetza ${ }^{\oplus}$ are extended release formulas. Riomet ${ }^{\oplus}$ is a liquid form. Five $\mathrm{mL}$ of Riomet ${ }^{\circ}$ is equal to a $500 \mathrm{mg}$ tablet form of metformin. The main effects of this agent are to acutely decrease hepatic glucose output by inhibiting mitochondrial respirator chain reactions. This causes hepatic energy production resulting in activation of AMP-activate protein kinase (AMPK). The exact mechanism by which metformin increases AMPK remains uncertain although it has been suggested that it does this by inhibiting glucagon-induced elevation of cyclic-AMP resulting in activation of protein kinase A $[32,33]$. Activation of AMPK requires an increase of small heterodimer partner (SHP), which in turn inhibits the expression of the hepatic gluconeogenic genes, phosphoenolpyruvate carboxy kinase (PEPCK), and Glucose-6 phosphatase (Glc-6-Pase) [34]. Metformin exhibits 
some toxicity to humans [6] with the most common adverse side effects being gastrointestinal symptoms, including diarrhea, cramps, nausea, vomiting, and increased flatulence [35]. Lactic acidosis can be fatal with metformin treatment at a frequency of 0.06 per 1000 patients per year [36].

Thiazolidinediones: Thiazolidinediones (TZDs) are novel treatment modalities for T2D. Fasting blood glucose and HbA1c can be improved on average about $40 \mathrm{mg} / \mathrm{dL}$ and almost $1 \%$, respectively. Three compounds of this class troglitazone $\left(\right.$ Rezulin $\left.^{\star}\right)$, rosiglitazone $\left(\right.$ Avandia $\left.^{\circ}\right)$, and pioglitazone $\left(\right.$ Actos $\left.^{\circ}\right)$ have been approved by the FDA. These drugs are potent agonists for the peroxisome proliferatorsactivated receptor-gamma (PPAR $\gamma$ ) receptor. Activation of the PPAR $\gamma$ nuclear receptor stimulates gene expression and synthesis of the glucose transporter -4 (GLUT-4). Translocation of GLUT-4 to the cell membrane stimulates glucose uptake by muscle and fat cells. This class of drug has little effect on hepatic glucose output but lowers plasma insulin levels and therefore improves insulin sensitivity in the muscle cells [37]. GLUT-4 gene expression can also stimulate gene expression of other unwanted genes. While TZDs are excellent anti-diabetic agents, they can pose moderate to severe untoward reactions. The first generation TZD, Rezulin ${ }^{\circ}$, was marketed in 1999 by Parks and Davis Pharmaceutical Co. One million patients used this drug and it was fatal in about 80 subjects. Avandia entered the market in 1999 and almost 4 million people in the US used it. Although it did not cause any fatal incidences, moderate to severe side effects associated with congestive heart failure, pulmonary edema, cardiac hypertrophy, and liver damage were documented $[7,8,37,38]$. It was estimated that the risk of hip and non-vertebral osteoporotic fracture increased 2-3 fold compared to those who did not take Avandia ${ }^{\circ}$ [39], and drug intake was correlated with liver failure and severe hepatotoxicity [40]. Peripheral edema was shown to increase 3-fold with Avandia treatment in comparison to control [41,42]. Macular edema incidence was also high with the consumption of Avandia ${ }^{\star}[43,44]$. In addition, upper respiratory tract infection, headache, and cough symptoms were also noted. Similar adverse reactions and a link with bladder cancers were also found to be associated with Actos $^{\oplus}[45,46]$.

Alpha-glucosidase inhibitors: Alpha-glucosidase inhibitors (AGIs) are saccharides that competitively bind to the membrane bound alpha-glucosidase. This binding inhibits carbohydrate digestion and conversion to glucose that can be easily absorbed by the small intestine. Hence, AGIs reduce glucose absorption and blood glucose levels. In healthy subjects, the AGIs are not only effective in delaying carbohydrate digestion, but are also effective in slowing down metabolic fermentation of carbohydrates in the colon [47] acarbose (Precose $\left.{ }^{\star}\right)$ is the most widely prescribed drug. Other AGIs include miglitol (Glyset ${ }^{\circ}$ ) and voglibose (Volix ${ }^{\oplus}$, Basen $\left.^{\star}\right)$. Compared to sulfonylurea, AGIs are inferior in glycemic control. However, these drugs can reduced fasting and postprandial plasma insulin and glucose levels, and are effective in decreasing $\mathrm{HbAlc}$ levels $0.77 \%$ with acarbose and $0.68 \%$ with miglitol treatment [48]; and may therefore delay or prevent diabetic complications [49]. It is generally recommended to start at a lower dose of acarbose and titrate up slowly to an effective dosage to avert gastrointestinal side effects found at the highest dosing.

GLP-1 and DPP-4 inhibitor: GLP-1 was effective in reducing HbAlc levels by $0.98 \%$ during a 16 week trial, but patients did experience gastric discomfort [9]. Another disadvantage of using this agent is that it must be injected subcutaneously [10]. Both GLP-1 and glucose-dependent insulinotropic polypeptide (GIP) are in a group of compounds called incretins, which are gastrointestinal hormones that increase insulin release from the pancreatic beta cells after eating. The mechanism of these hormones is to inhibit glucagon release from pancreatic alpha cells. The most commonly available GLP-1 product is Byetta ${ }^{\circ}$. There is a risk of acute pancreatitis with the use of GLP1[50]. GLP-1 is rapidly deactivated by DPP-4. DPP-4 inhibitors are commercialized as sitagliptin or Januvia ${ }^{\oplus}$. The combination of 100 mg DDP-4 inhibitor plus $2000 \mathrm{mg}$ metformin (Janumet ${ }^{\circ}$ ) treatment has been shown to decreased $\mathrm{HbAlc}$ levels $2.07 \%$ whereas metformin treatment alone only reduced HbAlc levels $1.3 \%$ (11). Since there is no serious side effect associated with the ingestion of DPP-4 inhibitor, this agent is considered a novel anti-diabetes agent for blood glucose control.

Bile acid sequestrants (BAS): BAS have been approved by the FDA for both glycemic and lipid control [51]. BAS are associated with the liver X receptors (LXR) and can lower blood glucose levels [52]. LXR activation improves insulin sensitivity by inhibiting the activity of PEPCK and G6Pase and therefore prevents gluconeogenesis [53]. LXR also improves glucose metabolism by promoting glucokinase and GLUT-4 gene expression in adipocytes [54] and by promoting insulin secretion from the islet beta cells [55]. Bile acids are natural ligands for the Farnesoid X receptor (FXR) and its activation in the liver increases the production of small heterodimer partners (SHP), which increases glucose metabolism by inhibiting production of PEPCK [56]. FXR activation also decreases blood glucose in rats [57]. Thus, FXR deactivation induces LXR activation and appears to have competitive effects on PEPCK. Also, LXR activity may overcome the effects of FXR deactivation [58]. BAS may also bind fat-soluble vitamins (Vitamins A, $\mathrm{D}, \mathrm{E}$ and $\mathrm{K}$ ) preventing uptake by the body [59].

\section{Obesity}

More than $80 \%$ of diabetic subjects are overweight or obese $[14,15]$. It has been reported that a body weight gain of 11-16 pounds increases the incidence of T2D more than twice that of normal subjects while a gain of 17-24 pounds increases the risk three times that of normal subjects [16]. It was also found that extensive counseling for diet and exercise can improve weight loss in obese adults, and improved glucose metabolism, lipid levels, and blood pressure. The prevalence of obesity doubled among adults between 1980 and 2004, and doubled again in between 2007 and 2008. Currently, the prevalence of obesity is $32.2 \%$ among adult men and $35.5 \%$ among adult women [60]. Obesity is associated with an increased risk of diabetes, cardiovascular disease [61], and is a major cause of morbidity and mortality in the US [14]. Each year, approximately 300,000 US adults die from obesity-related causes [14].

The estimated medical cost of obesity in the US was $\$ 78.5$ billion in 1998 and increased to $\$ 147$ billion in 2008 [62], and consumers spend about one-third of this amount for weight loss products and services [63]. The medical costs associated with obesity represents $9.1 \%$ of annual medical healthcare spending [63]. Healthcare costs for obese adults are $56 \%$ higher than for normal weight adults. In a study conducted at Cornell University in 2012 and published recently in Medical Daily, it was estimated that obesity now costs $\$ 190$ billion and accounts for almost $31 \%$ of the US healthcare cost. In another publication of Fair Food Network published in 2013, Tang et al. estimated that obesityrelated diseases and health problems accounts for $61 \%$ of healthcare cost in the US. Obesity is a preventable disease which is the leading cause of death worldwide [64]. It is estimated to account for 111,909 to 365,000 deaths/year in the US. Large scale studies have found that mortality risk is lowest in a population of people with a BMI in the 
normal range $\left(20-25 \mathrm{~kg} / \mathrm{m}^{2}\right)[65,66]$. On average, obesity reduces life expectancy by six to seven years. Obese subjects with a BMI of 30-35 $\mathrm{kg} / \mathrm{m}^{2}$ have a shortened life expectancy by two to four years and with a BMI $>40 \mathrm{~kg} / \mathrm{m}^{2}$, it is shortened by ten years $[7,67]$. The main cause of obesity is a combination of excessive food intake and a lack of physical activity due to easy access to high fat content foods and increased sedentary lifestyle which includes reliance on automobiles for even short trips and the increasing use of computers [68].

Pathophysiological mechanisms in developing obesity are attributed to hormonal effects [69]. Leptin is produced by adipose tissue and regulates fat storage in the body. It acts on a specific region of the brain, the satiety center, to regulate food intake, energy expenditure, and neuroendocrine function [70]. The leptin pathways are hormonal signaling pathways which signal from the adipose tissue to the brain to regulate energy balance [71. Human obesity is typically not due to a deficiency of leptin but due to central or peripheral leptin resistance or decreased leptin sensitivity. Leptin resistance is very similar to insulin resistance in muscle and fat cells. Thus, therapeutic augmentation of circulating leptin levels results in reduction of food intake, body fat mass, and body weight in many obese patients [72,73]. Circulating leptin levels are proportional to adiposity and increase with increasing body fat [74]. In addition to leptin, adiponectin, insulin, orexin, and ghrelin are also considered to influence appetite. Insulin also enters the brain, binds to its receptors in the hypothalamic nuclei and regulates central neural networks and energy balances. A schematic presentation of the key roles of brain insulin and leptin actions in the brains are shown in Figure 3.

\section{Currently recognized major anti-obesity agents}

Currently available drugs for the treatment of obesity either have an anorexic effect or inhibit lipase activity. Phentermine (ADIPEX-P ${ }^{\circledR}$ ), diethylpropion $\left(\right.$ Tenuate $\left.^{\circ}\right)$ and sibutramine $\left(\right.$ Meridia $\left.^{\circ}\right)$ are anorectic agents and orlistat $\left(\mathrm{Xenical}^{\oplus}\right)$ is a lipase inhibitor. Sibutramine was withdrawn from the US market in October 2010 due to serious side effects [75]. A meta-analysis concluded that none of these drugs give more than a $4 \mathrm{~kg}$ ( $4 \%$ or $4 \mathrm{~kg}$ ) weight loss greater than placebo [76].

Phentermine hydrochloride: It acts on the hypothalamus to stimulate adrenal glands to release epinephrine, which in turn signals reduced hunger and also induces fat cells to break down stored fat. However, the major effect is hunger reduction. Phentermine is generally considered well tolerated, although, since it acts through the sympathomimetic pathways, it can induce tachycardia, elevated blood pressure, palpitations, restlessness, and insomnia. Patients also reported dryness of mouth, unpleasant taste, diarrhea, and constipation. Long term use data showed no net weight loss. Thus, one must carefully weigh the benefits of phentermine against its side effects. It is also distributed under the tradename Adipex- $\mathrm{P}^{\circledast}$ in $37.5 \mathrm{mg}$ tablets and in capsules of $15 \mathrm{mg}, 30 \mathrm{mg}$ and $37.5 \mathrm{mg}$. The time for maximum plasma concentrations after administration $\left(\mathrm{T}_{\max }\right)$ is 3 to $4.4 \mathrm{hrs}$.

Diethylpropion (Tenuate ${ }^{ø}$ ): It is used for short-term weight reduction. It acts on the satiety center in the brain to cause a temporally reduction in appetite or hunger. This compound may indirectly elevate levels of leptin which is also known to suppress hunger. However, patients treated with diethylpropion can develop leptin resistance, in which high levels of leptin are not as active as in lean subjects. Diethylpropion stimulates the release of catecholamines, which suppress hunger signals and appetite. Catecholamine is known to halt neuropeptide $Y$, whose function is to initiate eating and decrease energy expenditure. Catecholamine doses for body weight control are variable. Its half-life biologically is 4 to 6 hours. Its adverse effects are tachycardia, arrhythmias, hypertension, and hypotension. It may induce dizziness, insomnia, euphoria tremor, and headache as-well-as dermatological, gastrointestinal, hematologic, and other miscellaneous minor side effects.

Orlistat $\left(\mathbf{X e n i c a l}^{\circ}\right)$ : It is the saturated derivative of lipstatin,

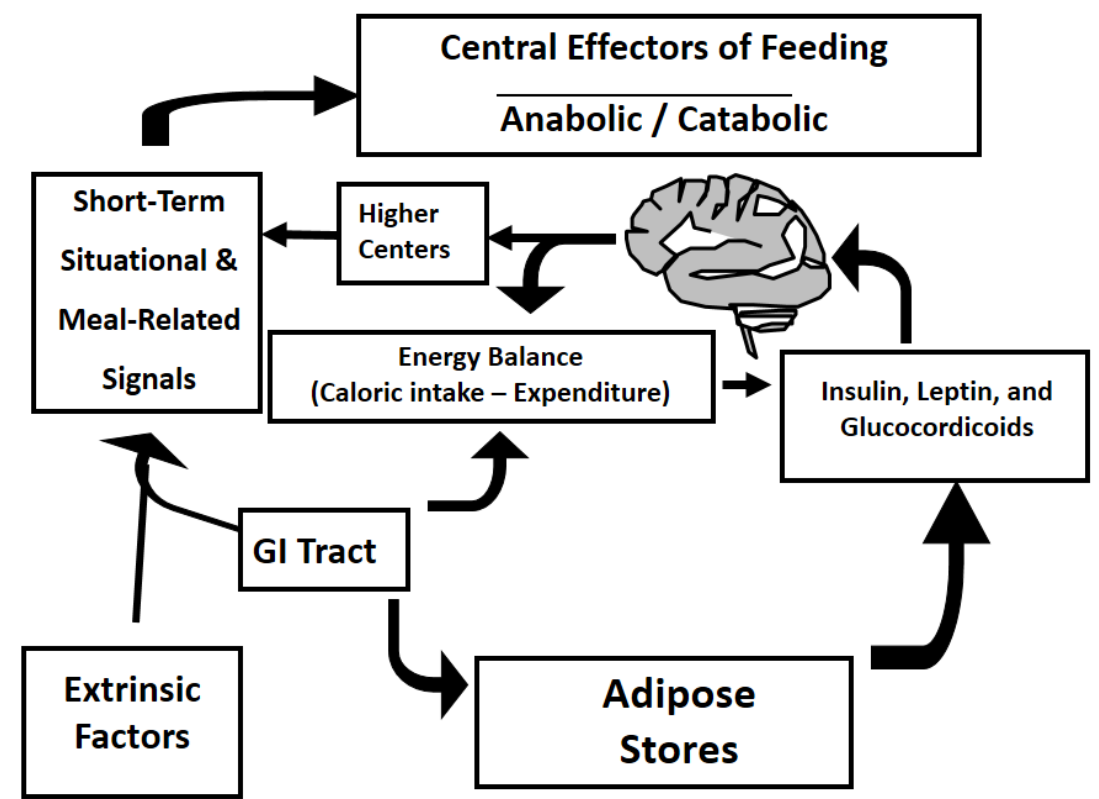

Figure 3: Mechanisms by which insulin and leptin regulate satiety, energy balance, and body weight. Adipose cells release leptin which signals the brain satiety center to inhibit hunger and appetite. Insulin performs a similar function as leptin but suppresses hunger to a lesser degree. Glucocorticoids antagonize the effect of leptin. Thus, the brain signals to balance calorie intake and expenditure, and leptin resistance and insulin resistance act together in the onset of obesity and diabetes. (Adapted from Ref 81 ). 
isolated from the bacterium Streptomyces toxytricini which is an inhibitor of pancreatic lipases. It is also known as tetrahydrolipstatin [77]. It functions by preventing absorption of fats by acting as a lipase inhibitor. Patients using orlistat lose about $2-3 \mathrm{~kg}$ more compared to controls over the course of a year [78]. Orlistat has been shown to moderately reduces blood pressure and prevent the onset of T2D by nearly $40 \%$ in obese people [79]. It has been shown in rare cases to induce acute kidney injury, possibly due to the increased fat malabsorption, and the formation of calcium soaps resulting in increased free oxalate absorption and enteric oxalosis, thus precipitating hyperoxaluric renal disease [80].

Methamphetamines: These are central nervous system stimulants used to treat attention deficit hyperactivity disorder, narcolepsy, and treatment-resistant depression under the trade name Desoxyn ${ }^{\oplus}$ [81], and in rare cases, for the treatment of obesity; although, its effect on obesity is mild. Obesity drug safety has been a major concern with the use of methamphetamines. Lorcaserin is classified as a controlled substance Schedule IV drug, fenfluramine was withdrawn from the market due to cardiac valvulopathy, phenylpropanolamine for hemorrhagic stroke, and ephedrine for cardiovascular and neurologic side effects [76].

Rimonabant: It is marketed in Europe and other countries. However, it was not approved in the US and has been withdrawn from the market due to the safety issue because of concerns over sucidailty, depression, and other related sides effects associated with th euse of this drug (http:// www.accompliarreport.com/News/news-061807.htm )

As Greenway and Caruso reported, excellent safe and effective anti-obesity drugs do not exist [82]. However, Bray [83] suggested that we should not abandon the currently available drugs and hope for future more effective drugs. Thus, a safe, effective, and affordable obesity medication is urgently needed.

Study Results from the New Drug Development Processing for the Prevention and Treatment of Diabetes and Obesity. $6=$

\section{Animal studies}

Blood glucose decreasing rates: Zinc treatment decreased fed blood glucose levels both in genetically T2D G-K rats without obesity (Figure 4) and in genetically obese T2D mice (Figure 5). Zinc or CHP alone was minimally effective in decreasing blood glucose levels. The optimal effective dose of CHP was $0.5 \mathrm{mg} / \mathrm{L}$ with $10 \mathrm{mg} / \mathrm{L}$ zinc, which is $0.1 \mathrm{mg} \mathrm{CHP} / \mathrm{kg} \mathrm{BW} /$ day based on the $\mathrm{BW}$ and daily water intake. This optimal dose of CHP is similar to that for the Three Hour Average above Fasting Glucose (TAFGC) reduction (Figure 6). However, the acute optimal dose of CHP is $0.5 \mathrm{mg} / \mathrm{Kg} \mathrm{BW}$ [84]. Blood glucose levels neither drop immediately nor do they decrease in a linear manner (Figure 5). It was also noticed that genetically heterozygous lean mice had slightly increased blood glucose during the 3-week treatment period. This means that Cyclo-Z does not appreciably alter blood glucose levels in non-diabetic animals.

Plasma insulin level changes by ZC treatment: Since ZC-treated diabetic rats and mice have decreased TAFGC and blood glucose levels, plasma insulin levels must increase if $\mathrm{ZC}$ effect is merely insulinemic. However, plasma insulin levels significantly decreased (Table 1), along with TAFGC and blood glucose levels in diabetic $\mathrm{G}-\mathrm{K}$ rats (Figures 4 and 6). Zinc or CHP treatment alone significantly increased plasma insulin levels in G-K rats showing zinc and CHP are insulin secretagogues. However, CHP plus zinc treatments invariably decreased plasma insulin levels in a CHP concentration dependent

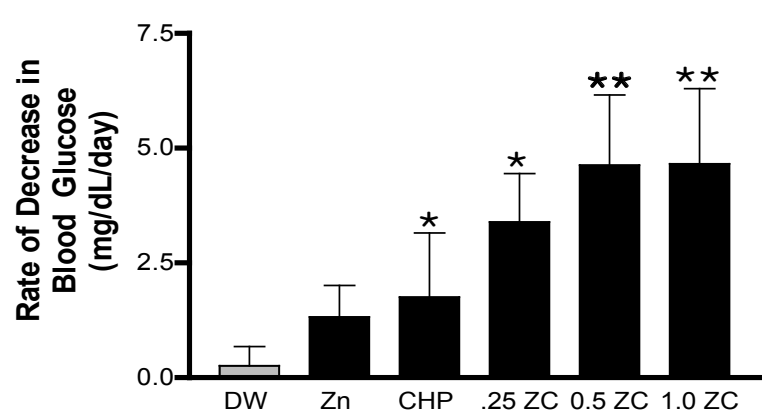

$(n=5-10) * p<0.05$ and ${ }^{* *} p<0.01$ vs. DW

Figure 4: Decreasing rates of blood glucose levels in G-K rats treated with various doses of ZC. Six-week-old diabetic G-K rats were treated with distilled water (DW), $10 \mathrm{mg} / \mathrm{L}$ zinc only $(\mathrm{Zn}), 1.0 \mathrm{mg} \mathrm{CHP}$ only $(\mathrm{CHP})$, or 0.25 $\mathrm{mg} / \mathrm{L} \mathrm{CHP} \mathrm{plus} 10 \mathrm{mg} / \mathrm{L}$ zinc $(0.25 \mathrm{ZC})$, or $0.5 \mathrm{mg} \mathrm{CHP}$ plus $10 \mathrm{mg} / \mathrm{L}$ zinc $(0.5$ $\mathrm{ZC})$ or $1.0 \mathrm{mg} / \mathrm{L} \mathrm{CHP}$ plus $10 \mathrm{mg} / \mathrm{L}$ zinc $(1.0 \mathrm{ZC})$ for 2 weeks.

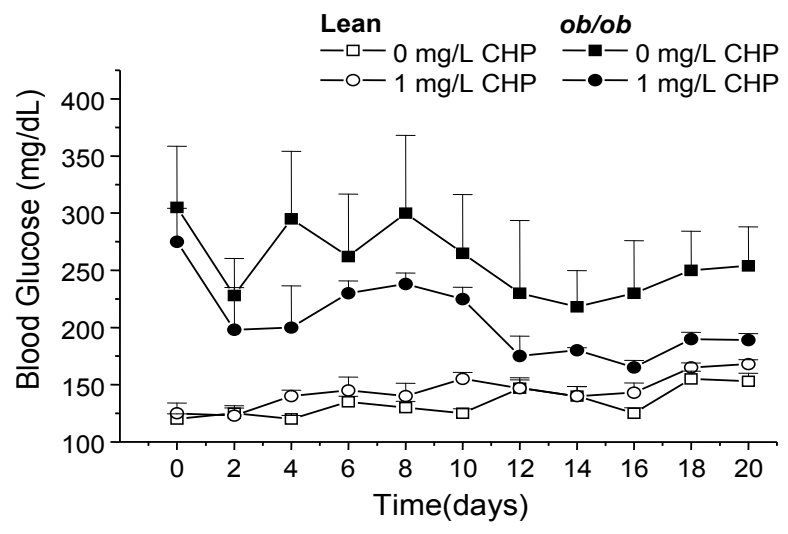

${ }^{*} \mathrm{p}<0.05$ compared to the mice treated with zinc only.

Figure 5: Effects of long term treatment with ZC on non-fasting blood glucose concentrations. Mice were treated either with $1.0 \mathrm{mg}$ of CHP plus $10 \mathrm{mg} / \mathrm{L}$ of zinc or with $10 \mathrm{mg}$ zinc/L only.

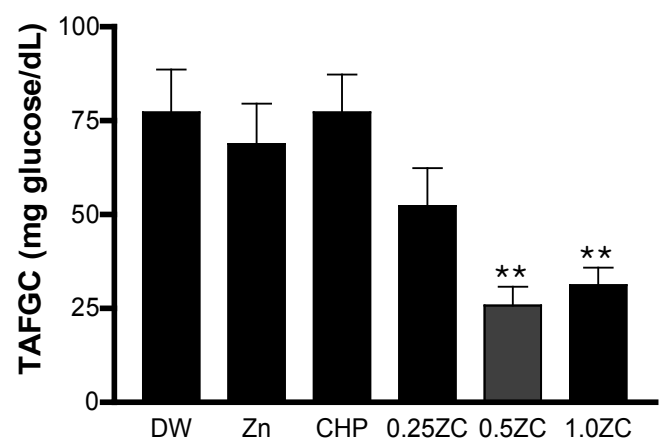

${ }^{* *} p<0.01$ vs. DW

Figure 6: CHP concentration-dependent effects of ZC on Three hour Average above Fasting Glucose Concentration (TAFGC) in G-K rats. TAFGC after bolus gastric gavage of $1.0 \mathrm{~g} / \mathrm{kg} \mathrm{BW}$ glucose in rats treated with distilled water (DW), with $10 \mathrm{mg} / \mathrm{kg} \mathrm{BW}$ zinc only (Zn), with $1.0 \mathrm{mg} / \mathrm{kg} \mathrm{BW}$ CHP Only (CHP), with $0.25 \mathrm{mg} \mathrm{CHP/kg} \mathrm{BW} \mathrm{plus} 10 \mathrm{mg} / \mathrm{kg} \mathrm{BW}$ zinc $(0.25$ $\mathrm{ZC})$, plus $0.5 \mathrm{mg} \mathrm{CHP} / \mathrm{kg}$ BW plus $10 \mathrm{mg} / \mathrm{kg} \mathrm{BW}$ zinc $(0.5 \mathrm{ZC})$, or plus 1.0 $\mathrm{mg} \mathrm{CHP/kg} \mathrm{BW} \mathrm{(1.0} \mathrm{ZC).} \mathrm{(n=5-10)} \mathrm{for} 2$ weeks. 
Citation: Song MK, Bischoff DS, Uyemura K, Song AM, Yamaguchi DT (2014) Prevention and Treatment of Obesity and Diabetes and their Related Complications. J Mol Genet Med S1: 009. doi: 10.4172/1747-0862.S1-009

manner with a fixed amount of zinc (Table 1). This phenomenon suggests that CHP plus zinc treatment improves insulin sensitivity and plasma insulin levels are low in untreated hyperglycemic rats because prolonged hyperglycemia blocks insulin secretion from pancreatic beta cells. The similar decrease of plasma insulin levels were also observed in $o b / o b$ mice with zinc treatment [85].

Body weight control by ZC treatment: When 10 month old G-K rats were treated with zinc only and with ZC for 4 weeks, body weight gain rates significantly decreased compared to the control (Figure 7) [86]. However, when these rats were given normal tap water for another 4 weeks; reduced body weight gain rate was still maintained only in ZC treated rats (Figure 8). These findings are similar to previous findings where improvement of insulin resistance in aged overweight S-D rats was maintained until one week after the cessation of ZC treatment [84].

Determination of optimal dose of CHP for reduction of BW: We established the optimal dose of $\mathrm{CHP}$ on $\mathrm{BW}$ reduction with different doses of CHP (1, 3, or $6 \mathrm{mg} / \mathrm{L}$ CHP plus $10 \mathrm{mg} / \mathrm{L} \mathrm{zinc})$ in drinking water for 15 days in overweight (650-850 g) S-D rats. The optimal dose for the reduction of BW in these rats was $3 \mathrm{mg} / \mathrm{L}$ CHP with $10 \mathrm{mg}$ zinc/L in drinking water (Figure 9), which was calculated as $0.1 \mathrm{mg}$ $\mathrm{CHP} / \mathrm{kg} \mathrm{BW/day,} \mathrm{similar} \mathrm{for} \mathrm{glucose} \mathrm{control} \mathrm{(Figures} \mathrm{4-6).}$

Baseline BW-dependent BW reduction by CHP plus zinc treatment: As shown in Figure 10, BW decreased most in the rats weighing over $1000 \mathrm{~g}(2.61 \pm 0.35 \mathrm{~g} /$ day; $\mathrm{p}<0.001)$, and less in the rats weighing $650-850 \mathrm{~g}(0.82 \pm 0.02 \mathrm{~g} /$ day; $\mathrm{p}<0.05)$. In contrast to the weight loss seen in overweight and obese rats, lean S-D rats weighing

\begin{tabular}{|c|c|c|c|}
\hline $\begin{array}{c}\text { Levels of zinc and } \\
\text { CHP in drinking water } \\
\text { (mg/dL) (n=5-10) }\end{array}$ & $\begin{array}{c}\text { Plasma Insulin (ng/ } \\
\mathbf{m L} \text { ) (Mean } \pm \text { SEM) }\end{array}$ & $\begin{array}{c}\boldsymbol{p} \text {-values* } \\
\text { compared to DW } \\
\text { only }\end{array}$ & $\begin{array}{c}\boldsymbol{p} \text {-values* } \\
\text { Compared to } \\
\text { CHP only }\end{array}$ \\
\hline DW & $0.457 \pm 0.028$ & --- & $<0.01$ \\
\hline Zinc Only $(10 \mathrm{mg} / \mathrm{L})$ & $0.637 \pm 0.048$ & $<0.05$ & $<0.05$ \\
\hline CHP Only $(1.0 \mathrm{mg} / \mathrm{L})$ & $0.907 \pm 0.090$ & $<0.001$ & ---- \\
\hline ZC $(10+0.25 \mathrm{mg} / \mathrm{L})$ & $0.817 \pm 0.167$ & $<0.01$ & $\mathrm{NS}$ \\
\hline ZC $(10+0.5 \mathrm{mg} / \mathrm{L})$ & $0.621 \pm 0.079$ & $\mathrm{NS}$ & $<0.05$ \\
\hline ZC $(10+1.0 \mathrm{mg} / \mathrm{L})$ & $0.552 \pm 0.092$ & $\mathrm{NS}$ & $<0.01$ \\
\hline
\end{tabular}

* One way ANOVA with multiple comparison (Bonferroni method) was performed to compare the values of DW and CHP treated rats.

Table 1: Plasma Insulin levels in G-K rats treated with various doses of ZC

Mature (10 months-UId) G-K Rats

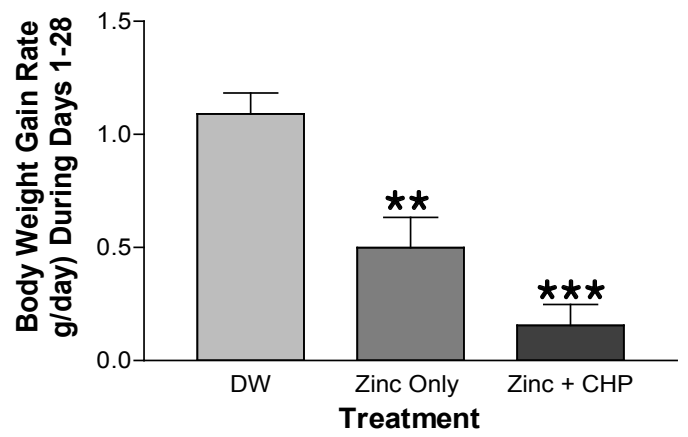

${ }^{* *} p<0.01$, and ${ }^{* * *} p<0.001$ vs. controls

Figure 7: Body weight reduction with ZC treatment. 10- month-old G-K rats were treated with drinking water containing no additive (DW), zinc $(10 \mathrm{mg} / \mathrm{L})$ alone, or ZC for 4 weeks and body weight measured throughout the treatment period.
After Transition to Inactive Therapy

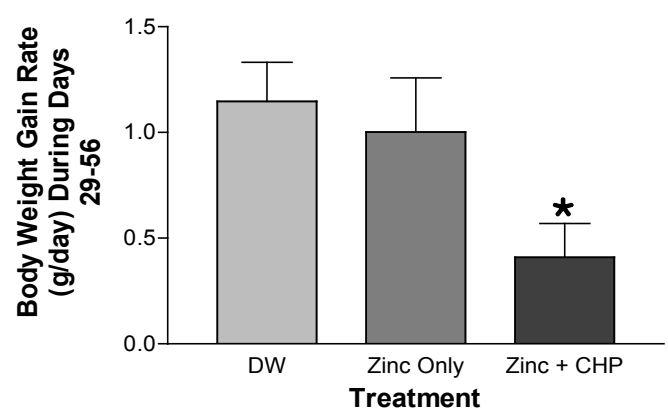

${ }^{*} p<0.05$ vs. controls

Figure 8: Maintenance of body weight reduction even after cessation of ZC treatment in G-K rats for an additional 4 weeks. Rats were treated similar to the DW controls.

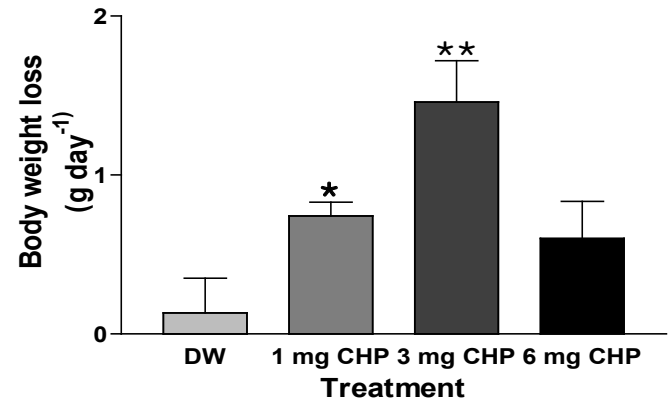

${ }^{*} \mathrm{P}<0.05,{ }^{* *} \mathrm{P}<0.01$ versus controls.

Figure 9: Effects of CHP doses on Body Weight Reduction. Body weight reduction in aged overweight S-D rats depends on CHP dose. Twenty-four 12-month-old S-D rats weighing 650-850 g were divided into four groups of six rats and treated with drinking water containing: (i) no additives; (ii) $1.0 \mathrm{mg}$ $\mathrm{CHP}+10 \mathrm{mg}$ zinc/liter; (iii) $3.0 \mathrm{mg} \mathrm{CHP}+10 \mathrm{mg}$ zinc/liter; or (iv) $6.0 \mathrm{mg} \mathrm{CHP}$ $+10 \mathrm{mg}$ zinc/liter for 15 days. The greatest weight reduction was seen in the rats taking water with $3.0 \mathrm{mg} \mathrm{CHP}+10 \mathrm{mg}$ zinc/liter.

350-450 g slightly gained BW at a low rate although the differences were still significant $(0.52 \pm 0.02 \mathrm{~g} / \mathrm{day} ; \mathrm{p}<0.001)$ (Figure 10). These data suggest that severely obese subjects could have more benefit than mildly obese subjects from ZC treatment, with little or no effect on lean non-obese subjects.

CHP plus zinc treatment decreased plasma leptin levels and increased plasma adiponectin levels in obese S-D rats: When non-diabetic obese aged S-D rats were treated with drinking water containing $3 \mathrm{mg} / \mathrm{L}$ CHP plus $20 \mathrm{mg} / \mathrm{L}$ zinc (ZC) for 4 weeks, the plasma leptin levels significantly decreased compared to controls $(\mathrm{P}<0.01)$ (Figure 11A). On the other hand, plasma adiponectin levels in these rats significantly increased compared to controls (Figure 11B). When non-obese lean diabetic mature $\mathrm{G}-\mathrm{K}$ rats were treated with drinking water containing the same amount of $\mathrm{ZC}$ as used for the obese S-D rats, plasma leptin levels slightly decreased compared to controls $(\mathrm{p}<0.05)$ (Figure 11A). However, plasma adiponectin levels did not increase in mature non-obese diabetic G-K rats (Figure 11B). The baseline values of leptin are higher in overweight aged S-D rats than in lean non-obese G-K rats, but adiponectin levels are lower in overweight aged S-D rats than in lean non-obese G-K rats. ZC treatment reversed these trends in 
Citation: Song MK, Bischoff DS, Uyemura K, Song AM, Yamaguchi DT (2014) Prevention and Treatment of Obesity and Diabetes and their Related Complications. J Mol Genet Med S1: 009. doi: 10.4172/1747-0862.S1-009

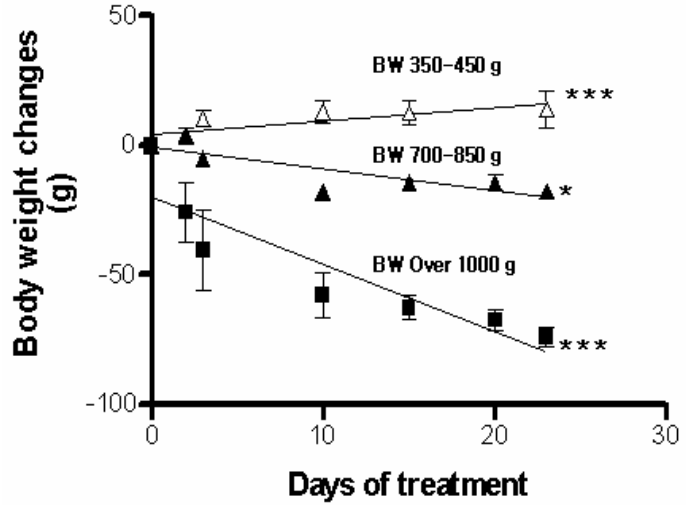

${ }^{*} \mathrm{P}<0.05,{ }^{* * *} \mathrm{P}<0.001$ from regression analyses.

Figure 10: Body Weight Reductions Depending on the Baseline Body Weight. Effect of ZC (3.0 mg CHP plus $10 \mathrm{mg}$ zinc/liter) on body weight of aged overweight $(700-850)$, obese $(>1000 \mathrm{~g})$, and lean $(350-450 \mathrm{~g})$ S-D rats depends on the initial body weight. Eighteen 6- to 18-months-old S-D rats were divided into three groups of six rats based on their body weights, and treated with drinking water containing $3.0 \mathrm{mg} \mathrm{CHP}$ plus $10 \mathrm{mg}$ zinc/liter. Both the obese and overweight groups lost weight over the 28 days of treatment but lean rats gained a small amount of weight.

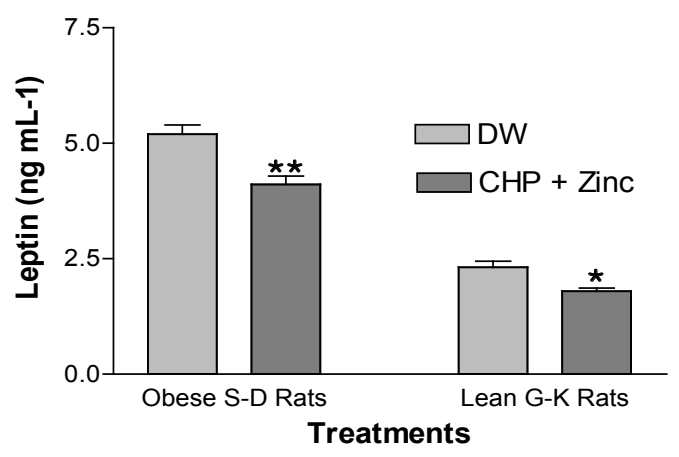

${ }^{*} \mathrm{P}<0.05 ;{ }^{* *} \mathrm{P}<0.01$ versus controls

Figure 11A: Comparison of plasma leptin levels between non-diabetic obese S-D rats and non-obese diabetic G-K rats. Fourteen 15-months-old male S-D rats weighing $650-850 \mathrm{~g}$ were given drinking water containing no additive or $3.0 \mathrm{mg}$ CHP plus $10 \mathrm{mg}$ zinc/liter and 3-month-old G-K rats were given drinking water containing either no additive or $1.0 \mathrm{mg} \mathrm{CHP}$ plus $10 \mathrm{mg}$ zinc/liter for 4 weeks. Rats with the ZC treatments showed reduced leptin level in both aged overweight S-D and lean diabetic G-K rats.

overweight S-D rats. These data suggest that CHP plus zinc treatment is very effective in the treatment of obese animals. BW reduction with decreasing plasma leptin levels and increasing adiponectin levels are an indication of improvement of leptin sensitivity similar to that seen with insulin sensitivity in diabetic G-K rats treated with ZC noted above.

Stimulation of insulin degradation in the cytosol of brain tissue in human amyloid precursor protein (APP) transgenic mice model: Insulin and amyloid proteins are degraded by Insulin degrading enzyme (IDE). Zinc is an integral part of IDE and is absolutely required for IDE enzymatic activity. IDE in the cytosol of brain samples from control animals require more than 20 minutes to degrade radiolabeled insulin whereas the cytosol from ZC treated animals degraded the majority of insulin within 15 minutes (left) (Figure 12). This is an approximately a $30 \%$ enhancement of IDE activity by ZC therapy (right) $(n=6)$. Hence,
Figure 12 supports the hypothesis that internalized insulin clearance may ameliorate diabetes.

\section{Human Studies}

Clinical trial with animal prostate substance plus zinc: Previous animal studies demonstrated that rabbit prostate extract (PE) stimulated intestinal zinc absorption and reduced blood glucose levels

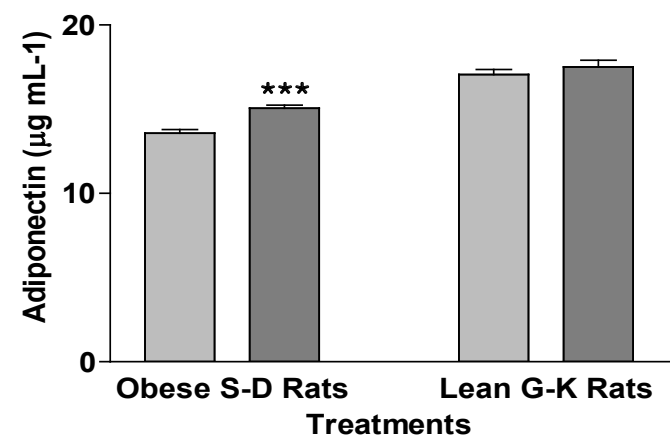

${ }^{* * *} \mathrm{P}<0.001$ versus controls.

Figure 11B: Plasma adiponectin levels in overweight non-diabetic S-D and lean diabetic G-K rats after ZC treatment. Fourteen overweight 15 -monthsold male S-D rats weighing $650-850 \mathrm{~g}$ were treated with drinking water containing either no additives or ZC ( $3.0 \mathrm{mg}$ CHP plus $10 \mathrm{mg}$ zinc/liter) and 3-month-old lean G-K rats with drinking water containing either no additives or ZC (1.0 mg CHP plus $10 \mathrm{mg}$ zinc/liter) for 4 weeks, and plasma adiponectin levels were measured at the end of the 4-week treatment period. Only the overweight S-D rats showed an increase in adiponectin levels at the end of the treatment period.
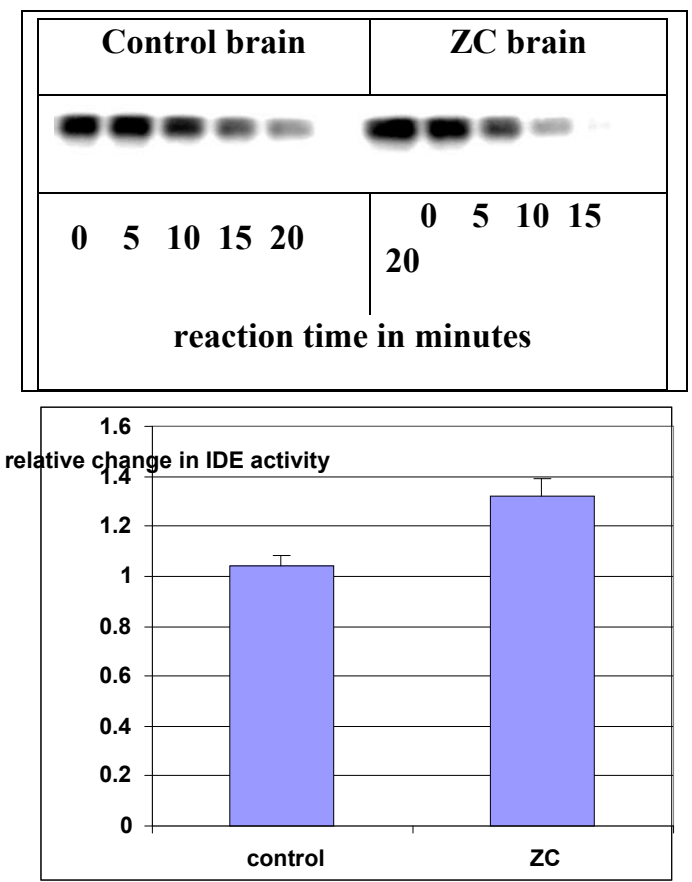

Figure 12: IDE Enzyme Activity on Insulin Degradation in ZC Treated Mouse Brain. IDE in the cytosol of brain samples from control animals require more than 20 minutes to degrade radio labeled insulin whereas the cytosol from ZC treated animals degraded $100 \%$ of insulin within 15 minutes (left). This is an approximately a $30 \%$ enhancement of IDE activity by ZC therapy (right) $(n=6)$. 
Citation: Song MK, Bischoff DS, Uyemura K, Song AM, Yamaguchi DT (2014) Prevention and Treatment of Obesity and Diabetes and their Related Complications. J Mol Genet Med S1: 009. doi: 10.4172/1747-0862.S1-009

Page 9 of 13

in streptozocin-induced diabetic rats [87]. In an attempt to translate these results to humans, we performed a clinical trial with $200 \mathrm{mg}$ prostate powder plus $20 \mathrm{mg}$ zinc containing gel capsule (Pro-Z) with FDA IND approval (IND \# 48,348) for diabetes treatment [88]. In this study, treatment of diabetic patients with 2-4 capsules of Pro-Z/day for three months significantly decreased TAFGC, HbAlc, and urine glucose levels as shown in Table 2. The patients reported no adverse side effects with Pro- $Z$ treatment. These data demonstrate that Pro- $Z$ is a potentially superior diabetes treatment agent compared to any of the other commercially available diabetes medications.

Phase 1 clinical trial with Cyclo-Z (3 mg CHP plus 20 mg zinc) gel capsule: We have performed a FDA required formal Phase 1 clinical trial using the anti-diabetes drug Cyclo-Z (Cyclo-[his-pro] plus zinc) after FDA IND approval (IND \# 61,897) on 49 healthy volunteers. The double-blinded study showed no adverse clinical side effects and no changes in blood chemistry data of subjects administered a onetime oral dose of $0,2,4$, or 8 capsules of Cyclo-Z in chemistry data and blood cell counts. Although subjects $(n=12)$ who took 8 capsules of Cyclo-Z before breakfast showed significantly reduced blood glucose levels at 8 hours, their plasma glucose levels were within normal range [89]. Blood glucose levels at twenty-four hours had returned to baseline levels prior to Cyclo-Z intake.

Phase2a clinical trials with Cyclo-Z: A Phase 2a clinical trial with Cyclo- $Z$ was initiated and prematurely terminated as the study subjects were mainly recruited from obese subjects with very mild diabetes (HbA1c levels between 6.1 and 8.0). In this first Phase2a trial, improvement of diabetic parameters was significant only in those patients with basal HbAlc levels above 6.9. However, the Body Mass Index (BMI) was significantly improved in these severely obese, mildly diabetic patients during the three months trial period with Cyclo-Z. We have recently initiating a second Cyclo- $Z$ clinical trial to be focused on severely obese, diabetic subjects with HbA1c levels above 8.0.

These studies strongly suggest that these two drugs are potentially very desirable anti-diabetes and anti-obesity agents. Most importantly, no side effects have ever been reported in patients enrolled in the clinical trials or by consumer's correspondence after more than 10 years of use by many diabetic subjects.

\section{Mechanisms of improving insulin sensitivity by Cyclo- $Z$ treatment}

IDE is a zinc containing enzyme and plays a major role in the regulation of internalized insulin degradation [90-92]. However, diabetic animals and humans are zinc deficient $[93,95]$ due to impaired intestinal zinc absorption and hyperzincuria [95-99]. Insulin-bound insulin receptor is transported to the endosome where it is separated from the receptor and the inactive insulin is degraded into peptides by IDEs and the peptides will be completely degraded into amino acids by lososomal enzymes. Insulin-receptors are then recycled or degraded into amino acids resetting the signal transduction pathway (Figure 13). If endosomal IDE levels are inadequate, undigested used insulin will remain in the cytosol preventing insulin signal transduction and synthesis or translocation of the glucose transporter-4 (GLUT-4)

\begin{tabular}{|c|c|c|c|c|}
\hline \multicolumn{5}{|c|}{ Treated with Pro-Z } \\
\hline Type of Medicine & Number of Patients & TAFGC $\quad(\mathrm{mg} \mathrm{G} / \mathrm{dl} / \mathrm{hr})$ & Hemoglobin A1C values & Urine Glucose Levels (mg/dl) \\
\hline $\begin{array}{c}\text { Pro-Z } \\
\text { Pre-treat } \\
\text { Post-treat } \\
\text { Difference } \\
\text { P }\end{array}$ & $N=22$ & $\begin{array}{c}140.5+9.2 \\
101.5+8.5 \\
39.0+9.6 \\
\mathbf{0 . 0 0 0 5}\end{array}$ & $\begin{array}{c}12.2+0.7 \\
9.5+0.5 \\
2.7+0.6 \\
\mathbf{0 . 0 0 0 3}\end{array}$ & $\begin{array}{c}1,249+236 \\
378+82 \\
871+240 \\
\mathbf{0 . 0 1}\end{array}$ \\
\hline $\begin{array}{l}\text { Placebo } \\
\text { Pre-treat } \\
\text { Post-treat } \\
\text { Difference } \\
\text { P }\end{array}$ & $\mathrm{N}=18$ & $\begin{array}{c}121.2+8.4 \\
126.4+8.0 \\
-5.2+9.4 \\
\mathbf{0 . 5 9}\end{array}$ & $\begin{array}{c}10.4+0.8 \\
10.2+0.6 \\
0.2+0.4 \\
\mathbf{0 . 5 9}\end{array}$ & $\begin{array}{c}877+175 \\
778+329 \\
99+365 \\
0.90\end{array}$ \\
\hline
\end{tabular}

Table 2: TAFGC, HbA1C, and Urine Glucose Levels in Type 2 Diabetic Patients.

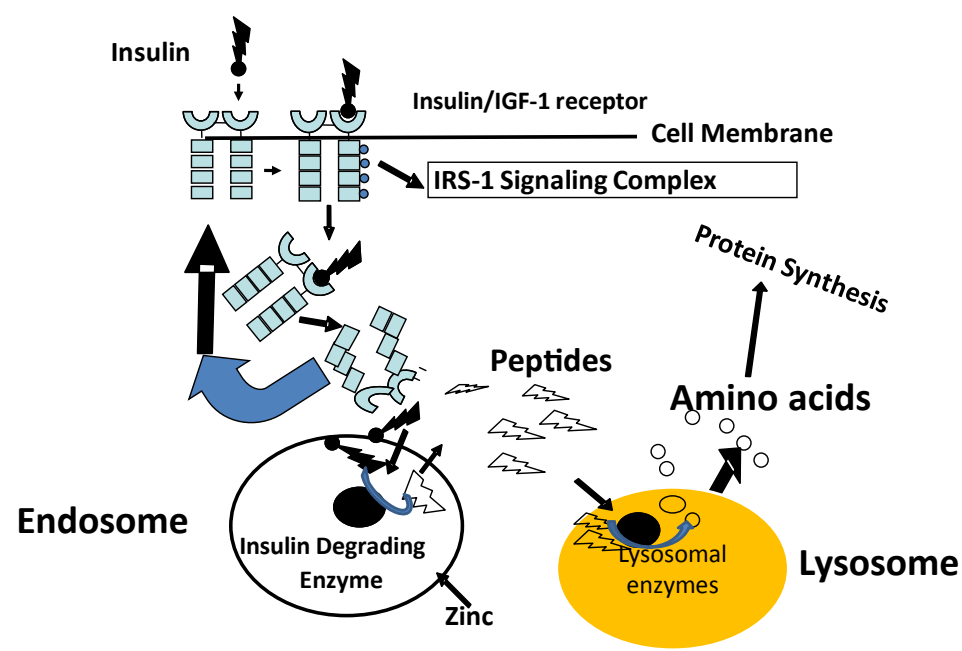

Figure 13: Degradation of used insulin in the muscle and fat cells. Insulin-bound insulin receptor is transported to the endosome where it is separated from the receptor and the inactive insulin is degraded into peptides by the insulin degrading enzyme (IDE) and then completely digested into amino acids by the lysosomal enzymes. Insulin-receptors are then recycled or degraded into amino acids. 
to the cell membrane for glucose uptake. IDE is therefore essential in maintaining insulin sensitivity [90-92]. Cyclo- $Z$ enhances IDE synthesis and stimulates insulin degradation (Figure 13). In addition, $\mathrm{CHP}$ enhances gene expression of factors that ameliorate diabetes and antagonizes factors that induce diabetes [100]. Although CHP or zinc alone is somewhat effective in the control of blood glucose metabolism, Cyclo- $Z$ may be the most effective agent in ameliorating insulin resistance in diabetes and obesity since it stimulates IDE synthesis and enhances beneficial gene expression for diabetes improvement.

\section{Mechanism of improving body weight control}

Zinc deficiency results in hypoleptinemia in animals [101] and in humans [102], and supplementation with zinc increases leptin synthesis [103]. Secretion of leptin is regulated by zinc in cultured rat adipocytes [104]. Leptin deficiency is associated with hyperphagia, hyperinsulinemia, and insulin resistance [105]. Administration of leptin reverses all of these findings in rodents [106]. Although leptin deficiency from a single homozygous gene mutation is associated with being overweight in humans, mutation of the leptin gene or its receptor is clinically rare [107]. However, in most obese animal models and humans, levels of plasma leptin are elevated [108,109], and age related diet-induced obese animals and humans generally exhibit leptin resistance [110]. CHP is found at concentrations as high as $0.3 \%$ $(\mathrm{w} / \mathrm{w})$ in parts of the hypothalamus (the satiety control center of the brain), and it has a cellular and subcellular localization distinct from thyrotropine releasing hormone (TRH) [111]. More importantly, CHP stimulates intestinal zinc absorption and muscle cell zinc uptake [112]. Thus, CHP may be an effective agent that stimulates zinc metabolism and regulates metabolic activities in the control of body weight. The effects of CHP plus zinc combinations on body weight was CHP dose dependent and related to plasma leptin levels and to adiponectin metabolism (Figure 11). Our data demonstrated that the reduction of BW induced by ZC treatment was accompanied by decreased plasma leptin levels. These observations suggest that ZC treatment may improve leptin sensitivity.

Treatment with CHP decreased food intake in rats, specifically fat and to some degree carbohydrate intake [113]. CHP reduces food intake by interacting with serotonin and fenfluramine in the brain, which are known anti-obesity agents [114]. Additionally, intraventricular administration of CHP has been shown to significantly reduced water intake [115]. We also found decreased water intake in older G-K and S-D rats after ZC treatment $[85,86]$. Young rats showed no difference in water consumption regardless of $\mathrm{ZC}$ addition to drinking water. Human obesity is polyfactorial not caused by a single gene mutation [116]. Environmental factors are likely to represent prime causative factors in modern obesity. Eating too many calories for one's energy needs combined with reduced energy expenditure contribute to obesity. Currently, no available drug induces loss of BW more than $4 \mathrm{~kg}$ in 2 years of treatment, and all current drug treatments have side effects. Our experimental data collectively suggest that Cyclo-Z treatment may help to reduce BW or BW gain without any adverse side effects. The mechanisms by which Cyclo- $Z$ treatment improves BW control may be via reduction of caloric intake and improvement of leptin sensitivity. The potential side effects of Cyclo-Z are not well understood. Side effects of zinc are well established during the last 50 years of study. In general its side effects are irritation of stomach other than megadose of more than $1 \mathrm{~g}$ of zinc element which could induce serious pathological condition and fatal if taken more than $10 \mathrm{~g}$ at a time. CHP side effects are not well established without any report of side effects but some studies of anti-toxicity of CHP have been published $[100,117,118]$. The long term side effect in humans will be established in our long term clinical trial and in the toxicological studies in dogs with high dose of Cyclo-Z for one year.

\section{Conclusions}

The most important anti-diabetes agents are those treating insulin resistances in diabetic patients. Both pioglitazone and rosiglitazone are effective in improving insulin sensitivity but pose several serious side effects [119]. Recent FDA rulings require warning labels for users of Avandia cautioning for potential hypercardia and liver damage, and for users of Actos ${ }^{\circledR}$ for bladder cancer. Most anti-diabetic drugs merely lower blood glucose temporarily, but pose moderate to serious side effects. Thus, it is highly desirable to have safe nontoxic medications for the treatment of diabetes. GLP-1 and DPP-4 inhibitor are relatively non-toxic but have drawbacks in that they must be injected subcutaneously and yet has a low effect on blood glucose reduction. Cyclo- $Z$ is a viable diabetes treatment that is similar to thiazolidinedione derivatives which improve insulin resistance but, most importantly, Cyclo-Z poses no known short-term side effects. Safety of anti-obesity drugs has also been a major concern. Essentially all anti-obesity drugs pose moderate to serious side effects and yet the most effective agent reduces body weight by only a maximum of $4 \mathrm{~kg}$ in the first year. Therefore, a safe, effective, and affordable anti-obesity medication would fulfill a presently unmet medical need. If we prove that Cyclo- $Z$ is safe and effective in the treatment of obese diabetics, Cyclo-Z may become an integral agent for treating diabetic and/or obese subjects. However, this optimism must be proven in Phases 3 and 4 clinical trials.

\section{References}

1. Daniel G, Finucane MM, Lu Y, Danaei G, Finucane MM, Lu Y, Singh GM, Cowan MJ, et al. (2011) National, regional, and global trends in fasting glucose and diabetes prevalence since 1980: Systematic analysis of health examination survey and epidemiological studies with 370 country -years and 2.7 million participants. Lancet 378: 31-40.

2. Hirschler B (2013) Diabetes battle 'being lost' as cases hit record 382 million Reuters.

3. Harris MI, Hadden WC, Knowler WC, Bennett PH (1987) Prevalence of diabetes and impaired glucose tolerance and plasma glucose levels in U.S. population aged 20-74 yr. Diabetes 36: 523-534

4. Bergman RN (1989) Lilly lecture 1989. Toward physiological understanding of glucose tolerance. Minimal-model approach. Diabetes 38: 1512-1527.

5. Kahn CR (1994) Banting Lecture. Insulin action, diabetogenes, and the cause of type II diabetes. Diabetes 43: 1066-1084.

6. Nawaz S, Cleveland T, Gaines PA, Chan P (1998) Clinical risk associated with contrast angiography in metformin treated patients: a clinical review. Clin Radiol 53: 342-344.

7. Papoushek C (2003) The "glitazones": rosiglitazone and pioglitazone. J Obstet Gynaecol Can 25: 853-857.

8. Kermani A, Garg A (2003) Thiazolidinedione-associated congestive heart failure and pulmonary edema. Mayo Clin Proc 78: 1088-1091.

9. Zinman B, Hoogwerf BJ, Durán García S, Milton DR, Giaconia JM, et al. (2007) The effect of adding exenatide to a thiazolidinedione in suboptimally controlled type 2 diabetes: a randomized trial. Ann Intern Med 146: 477-485

10. Gallwitz B (2005) New therapeutic strategies for the treatment of type 2 diabetes mellitus based on incretins. Rev Diabet Stud 2: 61-69.

11. Hanefeld M, Herman GA, Wu M, Mickel C, Sanchez M, et al. (2007) Once-daily sitagliptin, a dipeptidyl peptidase- 4 inhibitor, for the treatment of patients with type 2 diabetes. Curr Med Res Opin 23: 1329-1339.

12. Goldstein BJ, Feinglos MN, Lunceford JK, Johnson J, Williams-Herman DE; Sitagliptin 036 Study Group (2007) Effect of initial combination therapy with 
Citation: Song MK, Bischoff DS, Uyemura K, Song AM, Yamaguchi DT (2014) Prevention and Treatment of Obesity and Diabetes and their Related Complications. J Mol Genet Med S1: 009. doi: 10.4172/1747-0862.S1-009

sitagliptin, a dipeptidyl peptidase-4 inhibitor, and metformin on glycemic control in patients with type 2 diabetes. Diabetes Care 30: 1979-1987.

13. Boden G (2005) Study of obese diabetics explains why low-carb diets produce fast results. Science Daily. March issues of 2005

14. Sharma S, Jain S (2009) Prevalence of obesity among type 2 diabetes. J Human Ecol 25:31-35.

15. Flegal KM, Carroll MD, Ogden CL, Curtin LR (2010) Prevalence and trends in obesity among US adults, 1999-2008. JAMA 303: 235-241.

16. Colditz GA, Willett WC, Rotnitzky A, Manson JE (1995) Weight gain as a risk factor for clinical diabetes mellitus in women. Ann Intern Med 122: 481-486.

17. Malnick SD, Knobler H (2006) The medical complications of obesity. QJM 99: 565-579.

18. Barnes DE, Yaffe K (2011) The projected effect of risk factor reduction on Alzheimer's disease prevalence. Lancet Neurol 10: 819-828.

19. Whitmer RA, Gunderson EP, Barrett-Connor E, Quesenberry CP Jr, Yaffe K (2005) Obesity in middle age and future risk of dementia: a 27 year longitudinal population based study. BMJ 330: 1360 .

20. Meema HE, Meema S (1967) The relationship of diabetes mellitus and body weight to osteoporosis in elderly females. Can Med Assoc J 96: 132-139.

21. Hofbauer LC, Brueck CC, Singh SK, Dobnig H (2007) Osteoporosis in patients with diabetes mellitus. J Bone Miner Res 22: 1317-1328.

22. US. Preventive Services Task Force. (2003) Screening for obesity in adults: recommendations and rationale. Ann Intern Med 139: 930-932.

23. Wild S, Roglic G, Green A, Sicree R, King H (2004) Global prevalence of diabetes: estimates for the year 2000 and projections for 2030. Diabetes Care 27: $1047-1053$

24. Narayan KM, Boyle JP, Thompson TJ, Sorensen SW, Williamson DF (2003) Lifetime risk for diabetes mellitus in the United States. JAMA 290: 1884-1890.

25. Herman WH, Sinnock P, Brenner E, Brimberry JL, Langford D, et al. (1984) An epidemiologic model for diabetes mellitus: incidence, prevalence, and mortality. Diabetes Care 7: 367-371.

26. Geneva World Health Organization. (2009) Global health risks: Mortality and burden of disease attributable to selected major risks.

27. Mathers CD, Loncar D (2006) Projections of global mortality and burden of disease from 2002 to 2030 . PLoS Med 3: e442.

28. Hogan P, Dall T, Nikolov P; American Diabetes Association (2003) Economic costs of diabetes in the US in 2002. Diabetes Care 26: 917-932.

29. Zhang P, Zhang X, Brown J, Vistisen D, Sicree R, et al. (2010) Global healthcare expenditure on diabetes for 2010 and 2030. Diabetes Res Clin Pract 87: 293-301.

30. Martin AB, Whittle LS, Levit KR (2001) Trends in state health care expenditures and funding: 1980-1998. Health Care Financ Rev 22: 111-140.

31. Kahn CR (2003) The Gordon Wilson Lecture. Lessons about the control of glucose homeostasis and the pathogenesis of diabetes from knockout mice. Trans Am Clin Climatol Assoc 114: 125-148.

32. Rena G, Pearson ER, Sakamoto K (2013) Molecular mechanism of action of metformin: old or new insights? Diabetologia 56: 1898-1906.

33. Burcelin R (2013) The antidiabetic gutsy role of metformin uncovered? Gut.

34. Kim YD, Park KG, Lee YS, Park YY, Kim DK, et al. (2008) Metformin inhibits hepatic gluconeogenesis through AMP-activated protein kinase-dependent regulation of the orphan nuclear receptor SHP. Diabetes 57: 306-314.

35. Bolen S, Feldman L, Vassy J, Wilson L, Yeh HC, et al. (2007) Systematic review: comparative effectiveness and safety of oral medications for type 2 diabetes mellitus. Ann Intern Med 147: 386-399.

36. Wiholm BE, Myrhed M (1993) Metformin-associated lactic acidosis in Sweden 1977-1991. Eur J Clin Pharmacol 44: 589-591.

37. Saltiel AR, Olefsky JM (1996) Thiazolidinediones in the treatment of insulin resistance and type II diabetes. Diabetes 45: 1661-1669.

38. Kennedy FP (2003) Do thiazolidinediones cause congestive heart failure? Mayo Clin Proc 78: 1076-1077.
39. Papoushek C (2003) The "glitazones": rosiglitazone and pioglitazone. J Obste Gynaecol Can 25: 853-857.

40. Floyd JS, Barbehenn E, Lurie P, Wolfe SM (2009) Case series of liver failure associated with rosiglitazone and pioglitazone. Pharmacoepidemiol Drug Saf 18: $1238-1243$.

41. Mudaliar S, Chang AR, Henry RR (2003) Thiazolidinediones, peripheral edema and type 2 diabetes: incidence, pathophysiology, and clinical implications. Endocr Pract 9: 406-416.

42. Rosenstock J, Niggli M, Maldonado-Lutomirsky M (2009) Long-term 2-year safety and efficacy of vildagliptin compared with rosiglitazone in drug-naïve patients with type 2 diabetes mellitus. Diabetes Obes Metab 11: 571-578.

43. Ryan EH Jr, Han DP, Ramsay RC, Cantrill HL, Bennett SR, et al. (2006) Diabetic macular edema associated with glitazone use. Retina 26: 562-570.

44. Colucciello M (2005) Vision loss due to macular edema induced by rosiglitazone treatment of diabetes mellitus. Arch Ophthalmol 123: 1273-1275.

45. Azoulay L, Yin H, Filion KB, Assayag J, Majdan A, et al. (2012) The use of pioglitazone and the risk of bladder cancer in people with type 2 diabetes: nested case-control study. BMJ 344: e3645.

46. Lewis JD, Ferrara A, Peng T, Hedderson M, Bilker WB, et al. (2011) Risk of bladder cancer among diabetic patients treated with pioglitazone: interim report of a longitudinal cohort study. Diabetes Care 34: 916-922.

47. Wachters-Hagedoorn RE, Priebe MG, Heimweg JA, Heiner AM, Elzinga H, et al. (2007) Low-dose acarbose does not delay digestion of starch but reduces its bioavailability. Diabet Med 24: 600-606.

48. van de Laar FA, Lucassen PL, Akkermans RP, van de Lisdonk EH, Rutten $\mathrm{GE}$, et al. (2005) Alpha-glucosidase inhibitors for patients with type 2 diabetes: results from a Cochrane systematic review and meta-analysis. Diabetes Care 28: 154-163.

49. Bischoff $H$ (1995) The mechanism of alpha-glucosidase inhibition in the management of diabetes. Clin Invest Med 18: 303-311.

50. Singh S, Chang HY, Richards TM, Weiner JP, Clark JM, et al. (2013) Glucagonlike peptide 1-based therapies and risk of hospitalization for acute pancreatitis in type 2 diabetes mellitus: a population-based matched casecontrol study. JAMA Intern Med 173: 534-539.

51. Handelsman $Y$ (2011) Role of bile acid sequestrants in the treatment of type 2 diabetes. Diabetes Care 34 Suppl 2: S244-250.

52. Bays HE, Goldberg RB (2007) The 'forgotten' bile acid sequestrants: is now a good time to remember? Am J Ther 14: 567-580

53. Cao G, Liang Y, Broderick CL, Oldham BA, Beyer TP, et al. (2003) Antidiabetic action of a liver $\mathrm{x}$ receptor agonist mediated by inhibition of hepatic gluconeogenesis. J Biol Chem 278: 1131-1136.

54. Laffitte BA, Chao LC, Li J, Walczak R, Hummasti S, et al. (2003) Activation of liver $\mathrm{X}$ receptor improves glucose tolerance through coordinate regulation of glucose metabolism in liver and adipose tissue. Proc Natl Acad Sci U S A 100: 5419-5424.

55. Efanov AM, Sewing S, Bokvist K, Gromada J (2004) Liver X receptor activation stimulates insulin secretion via modulation of glucose and lipid metabolism in pancreatic beta-cells. Diabetes 53 Suppl 3: S75-78.

56. Ma K, Saha PK, Chan L, Moore DD (2006) Farnesoid X receptor is essential for normal glucose homeostasis. J Clin Invest 116: 1102-1109.

57. Zhang Y, Lee FY, Barrera G, Lee H, Vales C, et al. (2006) Activation of the nuclear receptor FXR improves hyperglycemia and hyperlipidemia in diabetic mice. Proc Natl Acad Sci U S A 103: 1006-1011.

58. Gupta S, Pandak WM, Hylemon PB (2002) LXR alpha is the dominant regulator of CYP7A1 transcription. Biochem Biophys Res Commun 293: 338-343.

59. Geil P, Shane-McWhorter L (2008) Dietary supplements in the management of diabetes: potential risks and benefits. J Am Diet Assoc 108: S59-65.

60. Bloomgarden ZT (2000) American Diabetes Association Annual Meeting, 1999 diabetes and obesity. Diabetes Care 23: 118-124.

61. Allison DB, Fontaine KR, Manson JE, Stevens J, Vanltallie TB (1999) Annual deaths attributable to obesity in the United States. JAMA 282: 1530-1538.

62. Finkelstein EA, Trogdon JG, Cohen JW, Dietz W (2009) Annual medica 
Citation: Song MK, Bischoff DS, Uyemura K, Song AM, Yamaguchi DT (2014) Prevention and Treatment of Obesity and Diabetes and their Related Complications. J Mol Genet Med S1: 009. doi: 10.4172/1747-0862.S1-009

spending attributable to obesity: payer-and service-specific estimates. Health Aff (Millwood) 28: w822-831.

63. Serdula MK, Mokdad AH, Williamson DF, Galuska DA, Mendlein JM, et al (1999) Prevalence of attempting weight loss and strategies for controlling weight. JAMA 282: 1353-1358.

64. Barness LA, Opitz JM, Gilbert-Barness E (2007) Obesity: genetic, molecular, and environmental aspects. Am J Med Genet A 143A: 3016-3034.

65. Berrington de Gonzalez A, Hartge P, Cerhan JR, Flint AJ, Hannan L, et al (2010) Body-mass index and mortality among 1.46 million white adults. N Engl J Med 363: 2211-2219.

66. Haslam DW, James WP (2005) Obesity. Lancet 366: 1197-1209

67. Prospective Studies Collaboration, Whitlock G, Lewington S, Sherliker $P$ Clarke R, et al. (2009) Body-mass index and cause-specific mortality in 900 000 adults: collaborative analyses of 57 prospective studies. Lancet 373: 1083 1096.

68. Bleich S, Cutler D, Murray C, Adams A (2008) Why is the developed world obese? Annu Rev Public Health 29: 273-295.

69. Flier JS (2004) Obesity wars: molecular progress confronts an expanding epidemic. Cell 116: 337-350.

70. Pelleymounter MA, Cullen MJ, Baker MB, Hecht R, Winters D, et al. (1995) Effects of the obese gene product on body weight regulation in ob/ob mice. Science 269: 540-543.

71. Kaiyala KJ, Woods SC, Schwart MW (1995) New model for the regulation of energy balance and adiposity by the central nervous system. Am J Clin Nutr 62: 1123S-1134.

72. Campfield LA, Smith FJ, Burn P (1996) The OB protein (leptin) pathway--a link between adipose tissue mass and central neural networks. Horm Metab Res 28: 619-632.

73. Campfield LA, Smith FJ (1998) Overview: neurobiology of OB protein (leptin). Proc Nutr Soc 57: 429-440.

74. Considine RV, Sinha MK, Heiman ML, Kriauciunas A, Stephens TW, et al. (1996) Serum immunoreactive-leptin concentrations in normal-weight and obese humans. N Engl J Med 334: 292-295

75. Rockoff JD, Dooren JC (2010) Abbot pulls diet drug Meridia off US shelves The Wall Street J.

76. Haddock CK, Poston WS, Dill PL, Foreyt JP, Ericsson M (2002)Pharmacotherapy for obesity: a quantitative analysis of four decades of published randomized clinical trials. Int J Obes Relat Metab Disord 26: 262-273.

77. Barbier P, Schneider F (1987) Synthesis of tetrahydrolipstatin and absolute configuration of tretrahydrolipstatin and lipstatin. Helvetica Chimica Acta 70: 196-202.

78. Rucker D, Padwal R, Li SK, Curioni C, Lau DC (2007) Long term pharmacotherapy for obesity and overweight: updated meta-analysis. BMJ 335: 1194-1199.

79. Torgerson JS, Hauptman J, Boldrin MN, Sjöström L (2004) XENical in the prevention of diabetes in obese subjects (XENDOS) study: a randomized study of orlistat as an adjunct to lifestyle changes for the prevention of type 2 diabetes in obese patients. Diabetes Care 27: 155-161.

80. Filippatos TD, Derdemezis CS, Gazi IF, Nakou ES, Mikhailidis DP, et al. (2008) Orlistat-associated adverse effects and drug interactions: a critical review. Drug Saf 31: 53-65.

81. Mitler MM, Hajdukovic R, Erman MK (1993) Treatment of narcolepsy with methamphetamine. Sleep 16: 306-317.

82. Greenway FL, Caruso MK (2005) Safety of obesity drugs. Expert Opin Drug Saf 4: 1083-1095.

83. Bray G (1998) Drug treatment of obesity: don't throw the baby out with the bath water. Am J Clin Nutr 67: 1-2.

84. Song MK, Hwang IK, Rosenthal MJ, Harris DM, Yamaguchi DT, et al. (2003) Anti-hyperglycemic activity of zinc plus cyclo (his-pro) in genetically diabetic Goto-Kakizaki and aged rats. Exp Biol Med (Maywood) 228: 1338-1345.

85. Hwang IK, Go VL, Harris DM, Yip I, Kang KW, et al. (2003) Effects of cyclo (his-pro) plus zinc on glucose metabolism in genetically diabetic obese mice. Diabetes Obes Metab 5: 317-324.
86. Song MK, Rosenthal MJ, Song AM, Uyemura K, Yang H, et al. (2009) Body weight reduction in rats by oral treatment with zinc plus cyclo-(His-Pro). Br J Pharmacol 158: 442-450.

87. Song MK, Rosenthal MJ, Kang KW, Adham NF, Mooradian AD, Ament ME (1996) Animal prostate extract ameliorates diabetic symptoms by stimulating intestinal zinc absorption in rats. Diabetes Res 31: 157-170.

88. Song MK, Rosenthal MJ, Naliboff BD, Phanumas L, Kang KW (1998) Effects of bovine prostate powder on zinc, glucose, and insulin metabolism in old patients with non-insulin-dependent diabetes mellitus. Metabolism 47: 39-43.

89. Uyemura K, Dhanani S, Yamguchi DT, Song, MK (2010) Metabolism and toxicicty of high doses of cyclo (His-Pro) plus zinc in healthy human subjects. J. Drug Metab Toxicol 1:105

90. Perlman RK, Rosner MR (1994) Identification of zinc ligands of the insulindegrading enzyme. J Biol Chem 269: 33140-33145.

91. Valera Mora ME, Scarfone A, Calvani M, Greco AV, Mingrone G (2003) Insulin clearance in obesity. J Am Coll Nutr 22: 487-493.

92. Trischitta V, Brunetti A, Chiavetta A, Benzi L, Papa V, et al. (1989) Defects in insulin-receptor internalization and processing in monocytes of obese subjects and obese NIDDM patients. Diabetes 38: 1579-1584.

93. Aguilar MV, Laborda JM, Martínez-Para MC, González MJ, Meseguer I, et al. (1998) Effect of diabetes on the tissular $\mathrm{Zn} / \mathrm{Cu}$ ratio. J Trace Elem Med Biol 12: $155-158$

94. Terrés-Martos C, Navarro-Alarcón M, Martín-Lagos F, López-G de la Serrana $\mathrm{H}$, Pérez-Valero V, et al. (1998) Serum zinc and copper concentrations and $\mathrm{Cu} / \mathrm{Zn}$ ratios in patients with hepatopathies or diabetes. $\mathrm{J}$ Trace Elem Med Biol 12: $44-49$

95. Song MK, Mooradian AD (1988) Intestinal zinc transport: influence of streptozotocin-induced diabetes, insulin and arachidonic acid. Life Sci 42: 687-694.

96. Kinlaw WB, Levine AS, Morley JE, Silvis SE, McClain CJ (1983) Abnormal zinc metabolism in type II diabetes mellitus. Am J Med 75: 273-277.

97. Ghishan FK, Greene HL (1983) Intestinal transport of zinc in the diabetic rat Life Sci 32: 1735-1741.

98. Johnson WT, Canfield WK (1985) Intestinal absorption and excretion of zinc in streptozotocin-diabetic rats as affected by dietary zinc and protein. $\mathrm{J}$ Nutr 115: $1217-1227$

99. Kiilerich S, Hvid-Jacobsen K, Vaag A, Sørensen SS (1990) 65 zinc absorption in patients with insulin-dependent diabetes mellitus assessed by whole-body counting technique. Clin Chim Acta 189: 13-18.

100. Choi SA, Yun JW, Park HS, Choi JW (2013) Hypoglycemic dipeptide cyclo (His-Pro) significantly altered plasma proteome in streptozocin-induced diabetic rats and genetically-diabetic (ob/ob) mice. Mol Biol Rep 40: 17531765 .

101. Mangian HF, Lee RG, Paul GL, Emmert JL, Shay NF (1998) Zinc deficiency suppresses plasma leptin concentration in rats. J Nutr Biochem 9: 47-51.

102. Mantzoros CS, Prasad AS, Beck FW, Grabowski S, Kaplan J, et al. (1998) Zinc may regulate serum leptin concentrations in humans. J Am Coll Nutr 17 : 270-275.

103. Huang W, Dedousis N, Bhatt BA, O'Doherty RM (2004) Impaired activation of phosphatidylinositol 3-kinase by leptin is a novel mechanism of hepatic leptin resistance in diet-induced obesity. J Biol Chem 279: 21695-21700.

104. Ott ES, Shay NF (2001) Zinc deficiency reduces leptin gene expression and leptin secretion in rat adipocytes. Exp Biol Med (Maywood) 226: 841-846.

105. Yildiz BO, Haznedaroglu IC (2006) Rethinking leptin and insulin action: therapeutic opportunities for diabetes. Int J Biochem Cell Biol 38: 820-830.

106. Pocai A, Morgan K, Buettner C, Gutierrez-Juarez R, Obici S, et al. (2005) Central leptin acutely reverses diet-induced hepatic insulin resistance. Diabetes 54: 3182-3189.

107.Stefan M, Nicholls RD (2004) What have rare genetic syndromes taught us about the pathophysiology of the common forms of obesity? Curr Diab Rep 4: $143-150$

108. Gallou-Kabani C, Vigé A, Gross MS, Rabès JP, Boileau C, et al. (2007) C57BL/6J and A/J mice fed a high-fat diet delineate components of metabolic syndrome. Obesity (Silver Spring) 15: 1996-2005. 
Citation: Song MK, Bischoff DS, Uyemura K, Song AM, Yamaguchi DT (2014) Prevention and Treatment of Obesity and Diabetes and their Related Complications. J Mol Genet Med S1: 009. doi: 10.4172/1747-0862.S1-009

109. Vona-Davis L, Howard-McNatt M, Rose DP (2007) Adiposity, type 2 diabetes and the metabolic syndrome in breast cancer. Obes Rev 8: 395-408.

110. Scarpace PJ, Tümer N (2001) Peripheral and hypothalamic leptin resistance with age-related obesity. Physiol Behav 74: 721-727.

111. Prasad C (1988) Cyclo(His-Pro): its distribution, origin and function in the human. Neurosci Biobehav Rev 12: 19-22.

112. Rosenthal MJ, Hwang IK, Song MK (2001) Effects of arachidonic acid and cyclo (his-pro) on zinc transport across small intestine and muscle tissues. Life Sci 70: 337-348.

113. Kow LM, Pfaff DW (1991) Cyclo(His-Pro) potentiates the reduction of food intake induced by amphetamine, fenfluramine, or serotonin. Pharmacol Biochem Behav 38: 365-369.

114. Prasad C, Mizuma H, Brock JW, Porter JR, Svec F, et al. (1995) A paradoxical elevation of brain cyclo(His-Pro) levels in hyperphagic obese Zucker rats. Brain Res 699: 149-153.
115. Ishihara H, Mori M, Kobayashi I, Kobayashi S (1985) Intraventricular administration of cyclo(His-Pro), a metabolite of thyrotropin-releasing hormone (TRH), decreases water intake in the rat. Proc Soc Exp Biol Med 178: 623-628.

116. Bouchard C, Tremblay A, Després JP, Nadeau A, Lupien PJ, et al. (1990) The response to long-term overfeeding in identical twins. N Engl J Med 322: 1477-1482.

117. Minelli A, Grottelli S, Mierla A, Pinnen F, Cacciatore I, et al. (2012) Cyclo(HisPro) exerts anti-inflammatory effects by modulating NF-î̄B and Nrf2 signalling Int J Biochem Cell Biol 44: 525-535.

118. Minelli A, Conte C, Grottelli S, Bellezza M, Cacciatore I, et al. (2009) Cyclo(HisPro) promotes cytoprotection by activating Nrf2-mediated up-regulation of antioxidant defence. J Cell Mol Med 13: 1149-1161.

119. Cheng-Lai A, Levine A (2000) Rosiglitazone: an agent from the thiazolidinedione class for the treatment of type 2 diabetes. Heart Dis 2: 326-333. 